\title{
Change in the Electrical Impedance Caused by Cornification of the Epithelial Cell Layer of the Vaginal Mucosa in the Rat
}

\author{
Masao KOTO, Masao MIWA, Ko-ichiro TSUJI, \\ Michio OKAMOTO, and Jiro ADACHI \\ Drug Development Laboratories, CHUGAI Pharmaceutical Co., Ltd., \\ Takada 3-41-8, Toshima, Tokyo 171, Japan
}

(Received 22 August 1986/Accepted 14 January 1987)

\begin{abstract}
The electrical impedance in the vagina (EIV) is significantly high in the proestrus stage compared with other stages of the estrous cycle in rats. Therefore, the EIV can be used to detect the optimum day for mating. The relation between the EIV and the conditions of the epithelial cell layer of vaginal mucosa were investigated. The EIV was at a high level (over $3,000 \Omega$ ) in vaginas in the proestrus stage in either intact or excised vaginal mucus. But it decrease (under 3,000 $\Omega$ ) after the epithelium of the vaginal mucosa was removed. The EIV of ovariectomized rats was low, but increased after Estradiol administration. The cornification of the epithelial cell layer of the vaginal mucosa occurred concurrently with the high EIV in the proestrus stage and after Estradiol administration. This indicates that the cornification of the epithelial cell layer of the vaginal mucosa may cause the elevation of EIV in the proestrus stage, the optimum day for mating in the rats.
\end{abstract}

\section{腔粘膜上皮の角化によるラットの腔インピーダンス (EIV) の変化}

古藤正男·三輪政大·边紜一郎・网本道生・安達二朗

\author{
中外製楽侏開発研究所
}

動物を計画的に交配し効率よく生産して行くためには 交配適期を正確に知ることが必要である。交配適期の判 定には種々の方法が用いられているが，その中でも発情 期の腔粘膜や子宮頸管粘液の物性変化を数量的に捉元， 明確に判定しようとする試みが盛んに行われるようにな った。牛, 羊, 山羊, 豚などの家畜では膣粘膜や子宮頸 管粘液の $\mathrm{pH}[14,15]$, 電気抵抗 $[5,6,8,17-19]$, 通電 性 $[1,15]$ などの物性が発情期を中心に変化することが 知られて抢り, それらは交配適期の判定に応用され，有
効な方法と評価されている。

実験動物においても, ラットおよびモルモットでイン ピーダンス（交流電気抵抗）を指標とした交配適期の判 定法が報告されている $[2-4,20]$ 。また，著者らは著者ら の開発した測定器を用いて Wistar-Imamichi 系ラット の性周期に伴う膣インピーダンス (EIV) の変化につい て観察し, EIV の值 $3,000 \Omega$ を境とし, それより高いと きはProestrus に，それより低いときは他の相に区別さ れ, EIV 測定がラットの交配適期の 判定に 利用でき, 
その的確率が高いことを報告した $[10]$ 。しかし，なぜ Proestrus に EIV が上昇するのかについての詳紼な検 討はない。ラットの腔の 性周期に伴う変化として $\mathrm{pH}$ $[9]$, 細菌数 $[9,11]$, 粘膜上皮の変化 $[7,13]$ などがあ り，いずれもが粘液あるいは粘膜のインピーダンスに影 響していると考えられる。また, 皮屇角化層が皮周インピ 一ダンスに大きく影響することが知られており $[21,22]$, 胵粘膜上皮の変化とくに Estrogen による粘膜上皮の角 化が粘膜インピーダンスに大きく影響し, EIV を上昇 させているのではないかと考えられる。そこで臸粘膜の 性状の変化, とくに角化と EIV の上昇との関係につい て検討した。

本報告はラットの Proestrus における EIV の上昇が Estrogen (卵胞ホルモン) の作用による臸粘膜上皮の角

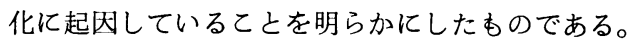

\section{林料および方法}

性周期が 4 日で回帰するように有種された Csk : Wistar-Imamichi 系ラット（自家繁殖）の $8 \sim 12$ 週粭此 を用いた。固形市販飼料 (CE-2: 日本クレア) と水（市 水之井水の混合水) を自由に攝取させ, 温度 $24 \pm 2{ }^{\circ} \mathrm{C}$, 湿度 50〜60\%，5 時点灯 19 時消灯に 設定された動物室 で，金網床ブラケット型ケージ $(660 \times 310 \times 220 \mathrm{~mm})$ に 10 匹づつ収容して群飼育した。EIV 测定方法掞よび 機器はすでに報告した通りである $[10]$ 。

性周期各相の EIV は無処置, 粘液除去, 粘膜上皮除 去の各処置群を設けた。まず EIV を測定したのち胵ス メアを採取してそのスメア像を観察し, 信永\&中村の判 定基準 [16] 亿従って性周期相を判定し, Proestrus, Estrus, Metestrus, Diestrus の 4 つの相を示すラット を各相 5 匹づつ用意した。次にラットを屠殺して腔を摘
出し，粘膜面をリン酸緩衝液（pH 6.8）でよく洗浄して 粘液を除去し，さらに脱イオン水でリン酸楥衝液を洗い 流し，余分な水分を瀘紙で除いたのち，その臸を測定用 プローブに巻きつけるようにして密着させてインピーダ ンスを測定した。この值を粘膜除去状態における EIV とした。リン酸緩衝液 ( $\mathrm{pH}$ 6.8) は第一リン酸ナトリウ ム 1 水塩 $5.92 \mathrm{~g}$ と第二リン酸ナトリウム 12 水塩 $54.52 \mathrm{~g}$ に蒸留水を加えて $1 \ell$ としたものを用いた。さらにその 臸の粘膜面をカミソリの刃で10回程度こすった後, 同様 にしてインピーダンスを測定した。この值を粘膜上皮除 去状態の EIV とした。これらの処置および測定は13時 から15時の間に速やかに行い，有意性の検定には $\mathrm{t}$ 検定 を用いた。

性周期各相の腔粘膜組織像を観察した。前述の粘液除 去状態の 性周期各相の胵を $10 \%$ ホルマリンで固定した 後, 常法に従ってパラフィン包理, 薄切, $\mathrm{HE}$ 染色を施 し鏡検した。材料の採取は13時から15時の間に行った。

また 4 日性周期を回㷌している雌ラット14匹の卵巣を 摘出し, 卵巣摘出後の EIV の変化を観察した。次に卵 巣摘出 4 週間後に性周期が消失していることを確認した 後，5匹に Estradiol-17 $\beta$ （以下 E2）を 9 時に皮下投 与し，投与後 $0,12,24,36,48,60,72,84,96$ 時間 の EIV を測定してその変化を観察した。投与量は予備 検討で明らかな EIV の上昇が得られた $20 \mu \mathrm{g}$ し, E2 は $100 \mu \mathrm{g}$ をオリーブ油 $1 \mathrm{ml}$ に溶解して用いた。対照とし て 5 匹にオリーブ油 $0.2 \mathrm{ml}$ を投与して 同様に観察した。 さらに 4 匹に E2 を同様に投与し，0，24，48，96時間 後における腔粘膜の組織学的観察に条 1 匹つうつ用いた。

\section{成}

性周期备相の䐋の無処置および粘液除去，粘膜上皮除

Table 1. The EIV under different conditions of the vaginal mucosa.

\begin{tabular}{|c|c|c|c|c|}
\hline \multirow{2}{*}{ Condition } & \multicolumn{4}{|c|}{$\operatorname{EIV}(\Omega)$} \\
\hline & Proestrus & Estrus & Metestrus & Diestrus \\
\hline Intact ${ }^{1}$ & $5,960 \pm 2,420^{* *}$ & $1,710 \pm 620^{a}$ & $1,670 \pm 430$ & $1,410 \pm 450$ \\
\hline After removing the mucus ${ }^{2}$ & $7,840 \pm 4,970^{* *}$ & $2,160 \pm 610$ & $980 \pm 430$ & $1,360 \pm 450$ \\
\hline After romoving the epithelia ${ }^{3}$ & $2,160 \pm 260$ & $1,720 \pm 590$ & $800 \pm 0$ & $1,280 \pm 440$ \\
\hline
\end{tabular}

1: Estrous stages were detected by vaginal smear cytology. The vaginal smear was taken after measuring the EIV in intact rats.

2: The mucus was washed off by phosphate buffer ( $\mathrm{pH} 6.8$ ).

3: The epithelia were scraped off with a razor brade.

**: Significant $(\mathrm{p}<0.01)$ compared with other stages under the same condition, a: mean \pm S.D. 
去の処置を行った状態での EIV を Table 1 亿示した。 各状態での值を性周期各相間で比較すると，無処置の場 合は Proestrus だけが有意に高く，他の相の間には差が なかった。粘液除去状態でもProestrus だけが有意に高 かったが，粘膜上皮除去状態では Proestrus の値は低下 し，他の相之差がなくなった。他の性周期相に関しては Metestrus で粘液除去により EIV の低下がみられたが, Estrus, Diestrusでは粘液, 粘膜上皮を除去しても EIV の変化はほとんどみられなかった。

4 日性周期を回帰し, 性周期に伴う周期的な EIV の 変化を示していたラットの卵巣を摘出すると, 性周期お よびそれに伴う周期的な EIV の変化は消失して EIV は 低值 $(800 \sim 1,200 \Omega)$ を維持した。こうした卵巣摘出ラ ットに E2 を投与した後の EIV の変化を Table 2 に示 した。 $\mathrm{E} 2$ 投与後の EIV は投与後36時間加ら上昇し, 48 時間には $5,000 \Omega$ に達し, その後低下して96時間には 0 時間の值に復帰した。一方, オリーブ油のみを投与し
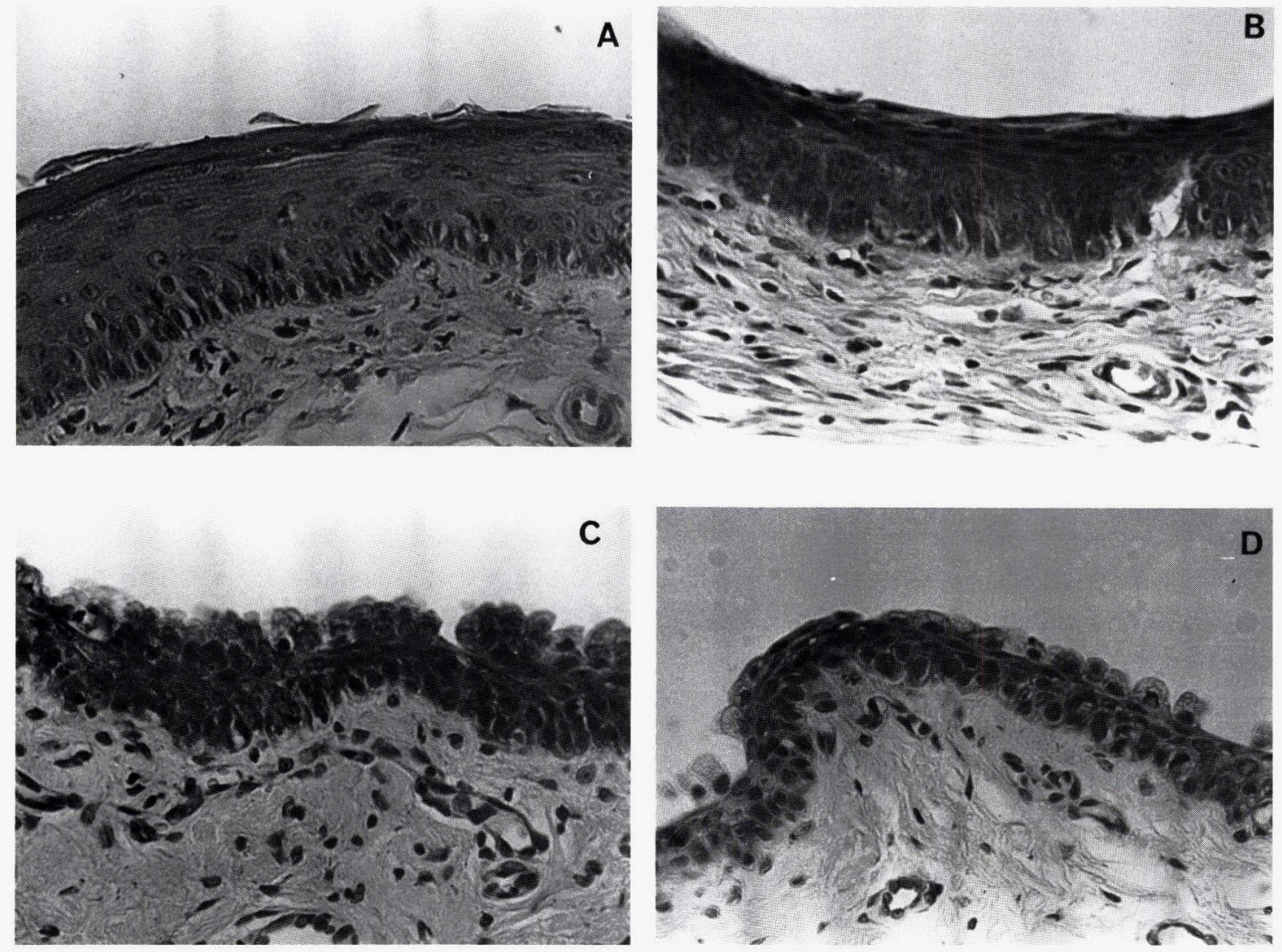

A : Proestrus. B: Estrus. C: Metestrus. D : Diestrus. Note the cornified epithelial cells in A.

Fig. 1. Vaginal mucosa from rats at the 4 stages of the estrus cycle.

\begin{tabular}{ccc}
\hline $\begin{array}{l}\text { Hours after } \\
\text { administration }\end{array}$ & $\begin{array}{c}\text { EIV } \\
\text { Control }\end{array}(\mathrm{n}=5)$ & $\begin{array}{c}(\Omega) \\
\text { Estradiol }^{2}(\mathrm{n}=5)\end{array}$ \\
\hline Pre & $820 \pm 110^{3}$ & $750 \pm 130$ \\
12 & $840 \pm 110$ & $820 \pm 150$ \\
24 & $1,080 \pm 180$ & $1,020 \pm 150$ \\
36 & $920 \pm 80$ & $1,480 \pm 260$ \\
48 & $900 \pm 100$ & $5,200 \pm 2,350$ \\
60 & $900 \pm 100$ & $2,320 \pm 720$ \\
72 & $880 \pm 110$ & $1,540 \pm 240$ \\
84 & $880 \pm 110$ & $1,360 \pm 230$ \\
96 & $900 \pm 140$ & $980 \pm 110$
\end{tabular}

1: Olive oil $0.2 \mathrm{ml}$ s.c.

2: $\beta$-Estradiol $20 \mu \mathrm{g} / 0.2 \mathrm{ml}$ of olive oil s.c.

3: $\operatorname{mean} \pm$ S.D.

た対照群では EIV は変化しなかった。

性周期各相の臸粘膜組織像を Fig. 1 亿示した。性周 期各相の臸粘膜の構築の違いは粘膜上皮にあり, 固有層 

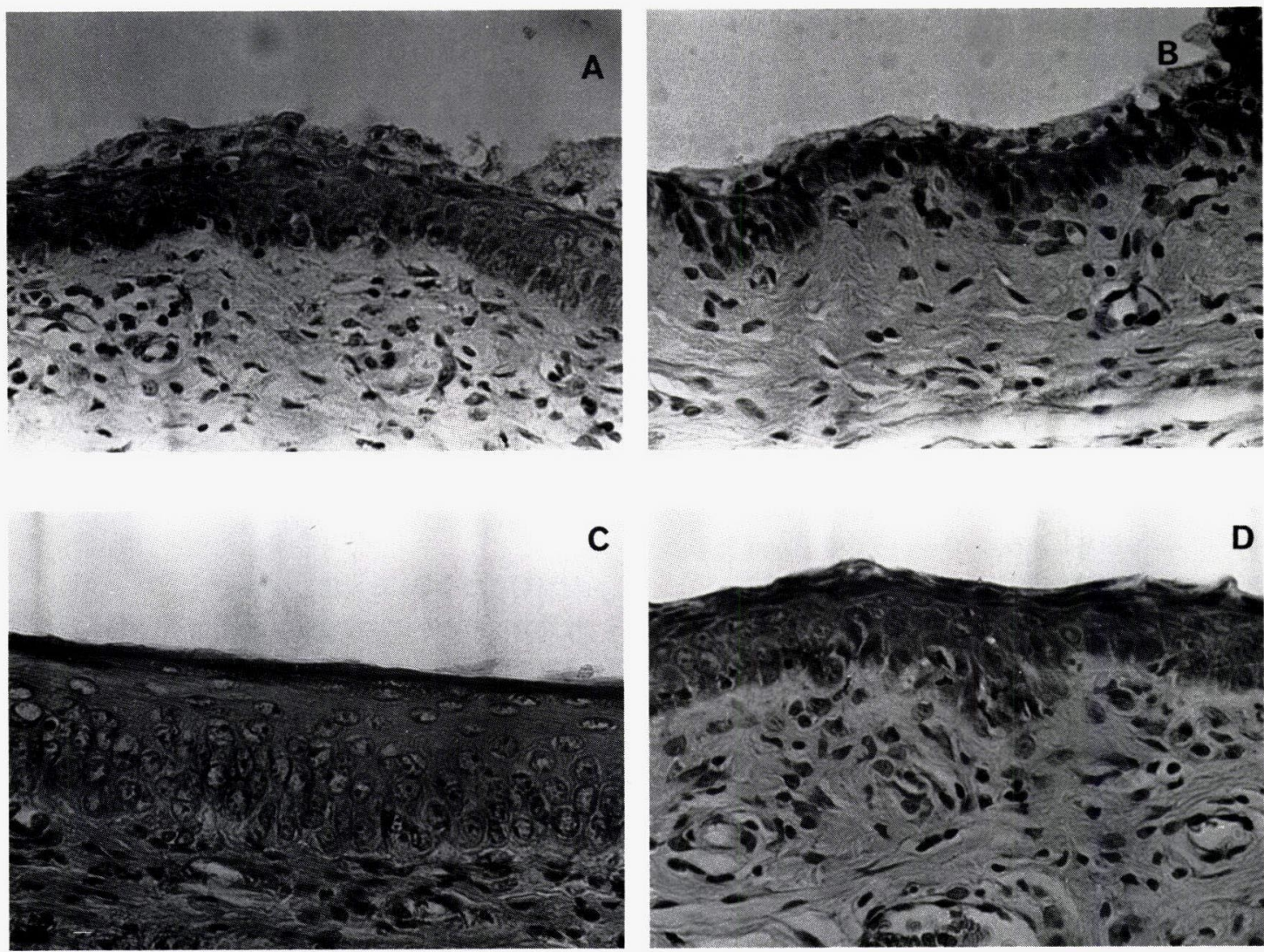

A : before. B: after 24 hrs. C: after 48 hrs. D: after 96 hrs. Note the cornified epithelial cells in $\mathrm{C}$.

Fig. 2. Change in the vaginal mucosa after Estradiol administration in ovariectomized rats.

以下には違いを認めなかった。Proestrus の上皮では角 化した上皮細胞の重積による角化層が形成されていた (Fig. 1-A)。また，Estrus の上皮は重層扁平上皮細胞 で, Metestrus, Diestrus の上皮は円形の上皮細胞で構 成されていた (Fig. 1-B〜D)。

卵巣摘出後のラットの $\mathrm{E} 2$ 投与前および投与後 24,48 , 96時間の胵粘膜上皮組織像を Fig. 2 亿示した。E2 投 与前および投与後 24 時間の臸粘膜上皮は Metestrus や Diestrusのそれと同じ円形の上皮細胞で被われていた。 投与後48時間の上皮では Proestrus のそれと同じ角化層 が形成され，96時間では Estrus のそれと同じ重層扁平 上皮細胞で被われていた。

\section{考 察}

Proestrus の EIV は無処置の場合には他の相に比し て有意に高く，粘液を除去した後も同様に高かった。し
かし腔粘膜上皮を除去すると大きく低下し, 他の相と差 がなくなった。他の相の值は腔粘膜上皮を除去しても大 きく変化しなかった。このことから Proestrusにおける $\mathrm{EIV}$ の上昇は, 腔粘膜の性状性質の違いによるものと 考えられた。Proestrus, Estrus においては粘液を除去 すると EIV が高まる傾向にあり, これらの相では粘液 が EIV をわずかに低下させているととも考えられる が, その変化は腔粘膜上皮除去による変化に比べて小さ く, 粘膜上皮の性状, 性質の違いの方が EIV に与える 影響がはるかに大きいと考えられる。

Proestrus と E2 投与後48時間の䐋粘膜上皮には角化 上皮細胞層が形成されており，乙の時期に一致して高い $\mathrm{EIV}$ が観察された。他の各相の腔粘膜上皮は円形の上 皮細胞あるいは扁平上皮細胞で構成 されており, EIV は粘膜上皮の角化之密接に関係しており, 角化により EIV が高まると考えられる。

E2 $20 \mu \mathrm{g}$ の投与は䐋スメア中への角化細胞出現に必要 
な量としては大量であると思われるが，明らかな EIV の上昇を示すような重層の角化層の形成には $20 \mu \mathrm{g}$ 程度 の $\mathrm{E} 2$ 投与が必要之考えられる。

また，ラットのの性周期各相の臸粘膜組織の構築につ いていくつかの報告があるが，今回の成績では買なる点 があった。すなわち，Long \& Evans の報告によれば stage 1 ( I ) の臸粘膜上皮は同時期に腔スメア中に認め られる円形上皮細胞で構築され，角化上皮は stage 2 （II）で認められている [13]。彼らの腔スメアによる性 周期の判定基準の stage 1（I）は信永\&中村の基準 [16] に従った今回の Proestrus と一致する。また，Fox \& Laird あ臸スメアに円形上皮細胞のみが認められるProestrus では臸粘膜上皮は円形上皮細胞で構築されている と報告している [7]。しかし，今可，Proestrus の腔粘 膜上皮には円形上皮細胞層は認められず，すでに重層の 角化上皮細胞層が形成されていた。これらの違いの原因 としては，用いているラットの系統が異なることや，材 料採取時刻，採取方法などに違いがある可能性が大きい こと，あるいは今回の検討では材料採取前に EIV を測 定していることなどが考えられる。

皮周インピーダンスに対する表皮角化層インピーダン スの影響は極めて大きく，とくに表皮に近い部分ほど抵 抗值が大きいこと，表皮を虽離していくと抵抗值が減じ てくることが知られている $[21,22]$ 。同様に臸粘膜にお いても粘膜上皮の角化層が抵抗值に大きく影響している と考えられる。

以上の乙とから，EIV は測定時の粘膜上皮が角化し ているか否かにより, その值は大きく変わり, ラットの Proestrusに拈ける EIVの上昇は Estrogenの作用によ る腔粘膜上皮の角化に起因していることが示唆された。

\section{要 約}

ラットの䐋の交流電気抵抗 (EIV) は Proestrus に高 い周期的な変化が認められ，交配適期の判定指標のひと つとして利用されている。今回，EIV の性周期に伴う 変化の起因を明らかにする日的で, ラットの臸粘膜之 EIV の值の関係について 検討した。Proestrus の日の EIV は粘液を取り除いても高值 $(3,000 \Omega$ 以上）を維持 したが，粘膜上皮を除去すると低值（3,000 $\Omega$ 以下）に なった。EIV が低值を維持している卵巣摘出ラットに Estradiol を投与すると投与 48 時間後に EIV は高值に なった。Proestrus 抢よび Estradiol 投与後の EIV が 高い時期には腔粘膜に必ず角化上皮細胞が観察された。
したがって、ラットの EIV が Proestrus に高く性周期 によあなって変化するのは, Estrogen によって膣粘膜 上皮が角化されることに起因していると考えられた。

\section{文献}

[1] Adam, L., Aizinbud, E., Tadmor, A., and Schindler, H. (1981). Impedometric properties of the vulvar and vaginal tissues of ewes during the estrous cycle. J. Reprod. Fert., 61, 11-17.

[2] Bartoš, L. (1975). Oestral cycle phase determination by means of electrical inpedance measurements of vaginal mucous membrane in rat. Physiol. bohemoslov., 24, 427.

[ 3 ] Bartoš, L. (1977). Vaginal impedance measurement used for mating in the rat. Lab. Anim., 11, 5355.

[4] Bartoš, L., and Sedláček, J. (1977). Vaginal impedance measurement used for mating in the guinea pig. Lab. Anim., 11, 57-58.

[ 5 ] Carter, P. D., and Dufty, J. H. (1980). Assesment of vaginal impedance measurements as an indicator of oestrus in cattle. Australian Vet. J., 56, 321323.

[6] Edwards, D. F., and Levin, R. J. (1974). An electrical method of detecting the optimum time to inseminate cattle, sheep and pig. Vet. Rec., 95, 416.

[7] Fox, R. R., and Laird, C. W. (1970). Sexual cycles. Reproduction and breeding techniques for laboratory animals, pp 115-118, Hafez, E. S. E. (edit.), Lea \& Febiger, Philadelphia.

[8] Gertland, P., Schiavo, J., Hall, C. E., Foote, R. H., and Scott, N. R. (1976). Detection of estrus in dairy cows by electrical measurements of vaginal mucus and by milk progesterone. J. Dairy Sci., 59, 982-985.

[9] Koiter, T. R., Hazenberg, M. P., and Van der Scott, P. (1977). Regulation of the bacterial microflora of the vagina in cyclic female rats. J. Exp. Zool., 202, 121-128.

［10］古藤正男·三輪政夫・富樫 守・辻紘一郎・岡本道生・安 達二朗 (1987)，腔電気インピーダンスによる4 日性周期 ラットの交配適期判定法。実験動物， 36，195-198。

[11] Larsen, B., Markovetz, A. J., and Galask, R. P. (1977). Relationship of vaginal cytology to alterations of the vaginal microflora of rats during the estrous cycle. Appl. Environment. Microbiol., 33, $556-562$

[12] Leidi, W., and Stolla, R. (1976). Measurement of electric resistance of the vaginal mucus as an aid for heart detection. Theriogenelogy, 6, 237-246.

[13] Long, J. A., and Evans, H. M. (1922). The oestrous cycle in the rat and its associated phenomena. Mem. Univ. Calf., 6, 1-148.

[14] 森純一・懀坦敏之（1965）。乳牛に打码雌生殖器内の $\mathrm{pH}$ の変化について。 日本獣医学雑誌，27，429.

［15］森 純一・富塚常夫・広木政昭・仮屋堯由（1979）。牛の 性周期中における子宮頸管粘液の $\mathrm{pH}$ ならびに電気伝導 度の変化一生体内測定による検討。家畜繁殖誌， 25，610.

[16］信永利馬 - 中村勝美 (1968). Wistar-Imamichi rat の 
性周期 (4 日) ならびにこれに伴う生理学的諸現象に関す る基礎検討 I . 胵坧像の連続的観察. 家畜繁殖誌, 14, 1-7.

[17] Podany, J., and Muzikant, J. (1970). Cyclic changes in electric resistance measured on the vaginal mucous membrane of cows and heifers during the sexual cycle. Vet. Med. (Praha), 15, 671-680.

[18] Podany, J., Muzikant, J., and Canderle, J. (1971), Electric resistance measured on vaginal mucous membrane in pregnant and non-pregnant sows. Vet. Med. (Praha), 16, 415-420.

[19] Podany, J., and Muzikant, J. (1972). Electric resistance measured in the vaginal mucous mem- brane in the course of the sexual cycle in goat and sheep. Vet. Med. (Praha), 17, 483-486.

[20] Teradach, C. (1982). Surveillance du cycle sexuel chez le rat par la mesure des variations de la valeur de l'impédance électrique au niveau de la cavité vaginale. Sci. Tech. Anim. Lab., 7, 49-54.

[21] 山本辰馬・山本尚武 (1973), 表皮角質層の電気物性につ いて，医用電子と生体工学，11，337-343.

［22］山本辰馬・山本尚武（1975）。表皮角質層の皘層構造を考 慮した皮㓓ンピーダンスについて。医用電子と生体工 学, 13, 201-206. 